\title{
The Research of the Publicistic Style in the Creative Activity of the Representatives of Nakhchivan Literary Environment at the End of XIX Century and at the Beginning of XX Century
}

\author{
Mehriban Asadullasoy (1) \\ Nakhchivan State University, Azerbaijan \\ Email: quliyeva.mehriban@list.ru
}

How to cite this paper: Asadullasoy, M. (2021). The Research of the Publicistic Style in the Creative Activity of the Representatives of Nakhchivan Literary Environment at the End of XIX Century and at the Beginning of XX Century. Advances in Literary Study, 9, 197-208.

https://doi.org/10.4236/als.2021.94021

Received: July 24, 2021

Accepted: October 22, 2021

Published: October 25, 2021

Copyright $\odot 2021$ by author(s) and Scientific Research Publishing Inc. This work is licensed under the Creative Commons Attribution International License (CC BY 4.0).

http://creativecommons.org/licenses/by/4.0/

\begin{abstract}
The work of the representatives of the Nakhchivan literary environment at the end of the XIX century and at the beginning of the XX century in the field of publicism has been investigated in this article. The activity of the writers who had an exceptional role in the development of the literary language in the press was recorded systematically and at the same time, the linguistic features of the publicistic style of the Azerbaijani literary language have been researched. In the article not only the publicistic heritage of the representatives of Nakhchivan literary environment at the end of the XIX century and at the beginning of the XX century was investigated but also the language-style features of the articles of the literary environment representatives who worked in this field have been analyzed. In the publicism of the writers from Nakhchivan, the writing professionalism displayed it distinctly and they benefited from its strong description means. Different from fiction, publicism reaches the readers quickly through the pages of the newspapers and discusses the hot topics of daily life. In this meaning, the publicistic articles of the representatives of the literary environment not only create the socialpolitical scene of the time they lived but also with the artistic language qualities describe that time in detail.
\end{abstract}

\section{Keywords}

Publicism, Nakhchivan, Literary Environment, Style, Newspaper Language

\section{Introduction}

Actuality of the topic. At the end of the XIX century and at the beginning of 
the XX century the representatives of Nakhchivan literary environment operated tirelessly in the publicism, fulfilled honorable missions in the way of to introduce our ancient and rich material-spiritual heritage, enlighten the people, and strengthened the base of the publicistic tradition.

The publicism propagated enlightenment ideas, classical fiction and enriched our literary language, played an unexampled role in the evolution of society. Researching such publicism in the creative activity of Nakhchivan literary environment increases the history of classic publicism.

The idea-aesthetic features of the publicistic articles, to investigate the style richness attentively and comprehensively in the creative works of the representatives of Nakhchivan literary environment will contribute to the development of the publicism.

Object of the article. The object of the article is to appreciate the works of the writers from Nakhchivan at the end of the XIX century and at the beginning of the XIX century by investigating and analyzing and to ground the role in the formation of the national consciousness of the people.

Purposes and duties. The purpose of the article is to research comparative-analytical method the social-political view of the period the representatives of the Nakhchivan literary environment lived. To reveal scientifically the theme of the publicism, artistry problems, the attitude to the events, the opinion of the important problems of the people, theme-idea and structure features, genre matters, the skillfulness and typicalness of the problem, style, language, and quality make the theme to be more comprehensive. In order to gain those purposes, the solution of the following duties has been put forward in the article.

The tireless activity of the representatives of Nakhchivan literary environment who lived and created at the end of XIX century and at the beginning of XX century, to research their activity that secures the development of national culture, language, and literature.

To ground the power of the publicism that the intellectuals of Nakhchivan used to strengthen the democratic inclinations, to enlighten the people, to call them to the struggle for their rights, to propagate national self-consciousness;

To ground the importance of the struggle for the literary language from a national self-consciousness point of view with concrete publicistic examples;

To ground the importance of eminent public figures, the enlivening of the national consciousness with the concrete publicistic examples;

To define the language and style features of the press organs that the writers of Nakhchivan founded and took and were active at the end of XIX century and at the beginning of XX century.

The artistic features of the publicistic works published in the magazines as "Sherqi-Rus" ("Eastern-Russian") and "Molla Nasraddin": to analyze from point of view of genre, style, language, artistry.

Method of the article. The theme of the dissertation was researched by grounding on the historical-comparative investigating method, referenced to the articles of the classics, to the thoughts of the eminent scientists who research that 
field. The modern scientific-theoretical principles and the research methods that were used in the research works were dedicated to the Azerbaijani press, publicism at the beginning of XX century. The objectivity principle was kept in the article, the works of the writers of Nakhchivan who lived at the end of XIX century and at the beginning of XX century were investigated in the article. The author of the article not only was satisfied with the studying of the problem and collecting of the factual materials, but also made efforts to analyze those facts and works deeply and in details.

Innovation of the article. The service of the eminent public figures and intellectuals in enriching the artistic language, their role in the publicism, their opinions against the colonization, their struggle and national liberty ideas have been reflected in the article, and the role of the literary language, national culture have been defined. The author of the article not only dealt with the role of press in the development of our literary language at the end of XIX century and at the beginning of XX century, but also dealt with the important factors that influenced the enlightenment of the national enlivening of the people.

\section{The theoretical and practical importance of the article.}

The researchers who study the history of the publicism of the literary environment of Nakhchivan, the specialists who work in the field of humanitarian field, the scientists, teachers and students can benefit from the thesis that was put forward in the research work and the scientific results.

At the end of XIX century and at the beginning of XX century the publicism dealt with the important problems of the people, and the representatives of Nakhchivan literary environment had their own publicistic style, and their style turned to the reality, actual problems of the centuries, and so it is necessary to bring that theme to the agenda. The progress of mankind, the awakening of national consciousness and the press, as well as literature, in the rise of the process of national self-awareness has a place and importance. However, Jonathan D. Fitzgerald writes that there are some differences between these two styles: Even as literature and journalism shared in the shift toward realism, however, this similar path led to some of the early problems that would eventually grow into a full-blown rift. On one hand, the fact that realistic fiction and narrative newspaper writing looked similar led to a sense of competition between the two (Fitzgerald, 2017).

The representatives of Nakchivan literary environment could be able to write the facts or life realities skillfully, well-aimed manner of expression, original style of their articles and feuilletons are interesting and estimable. The writers collaborated with the press organs, and their artistic publicism had satire having secret hints including the original style that caused the reader to think over and over. Firstly in this article, the artistic language features of the activity of the representatives of Nakhchivan literary environment at the end of XIX century and at the beginning of XX century have been investigated systematically in new approach.

At the beginning of XX century, the complicated social-political events hap- 
pened in Azerbaijan were brought to publicism by the publicist of that time. Our educational intellectuals who played a great role in the process of national awakening and national self-consciousness displayed exceptional services in the publicism field of literary activity. The eminent representatives of the Azerbaijan publicism demonstrated self-devotion in the creation of the press and leaning on the miraculous power of the artistic word and began to publish the articles that delivered the words directly to the addresses. Publicistic style created great opportunities in immortalizing the traditions of classic press in Azerbaijani literary language and in enriching the stylistic opportunities of the vocabulary of our language, including publicistic style created broad opportunities in gaining popularity of literary language.

The different functional styles of the literary language are the field that functions harmoniously with the events happening in the society. The functional styles of the literary language have universal features and are used for mass communication. Any kind of mass information is delivered to the people by the speeches in the newspaper, radio, television and meetings and gatherings mainly in publicistic style (Qurbanov, 1992).

As a result of self-devotion of Hasan bey Zardabi, the founder of national press, "Akinchi" ("The Ploughman") was published and by the publishing of that newspaper the foundation of publicistic style of literary language was put. Tofig Hajiyev wrote as follows: "In the spiritual history 'Akinchi' is such an object any researcher might deal with it according to their profession. The historical turning connecting with our subject is that 'Akinchi' created a new style in the history of our literary language." This was the last style of our literary language, that is to say, the publicistic style. With that style, our literary language attained its many versioned forms that were demanded from the national literary language (Hajiyev, 2012).

\subsection{The Publicism of the Representatives of Nakhchivan Literary Environment at the End of XIX Century and at the Beginning of XX Century, the Idea-Aesthetic Features and Style Richness of Their Publicism}

So, in the initiative of our eminent intellectuals, the publicistic style was created at the second half of XIX century. The newspaper "Akinchi" that was based on the enlightenment idea had special role in the development of the national intellectuals' generation, especially in the issue of term creation. Of course, in term creation the newspapers preferred the materials in the mother tongue, the national terms were taken from the life of the daily life of the people, and were brought to the pages of the newspaper, that is to say, to the literary language of that time, and they preferred the people's terminology (Mehdiyeva, 2007).

At the beginning of XX century the satirists who had much more experience alongside by bringing people's speaking language to the literary language, could achieve to include new memorable words and phrases to the lexicon of the peoples. The publicistic style drew the attention with the democratism of its vo- 
cabulary and mass speech appearance is mass speaking form and is close to the common speaking language, and that is why could gather around all the classes of its time, and could reflect their interests in its pages.

The publicism of the representatives of the literary environment draw attention to its idea-aesthetic features, and style richness and artistic merit. The publicistic style is the expression of the phrases clearly to the reader. In the comparison of the artistic style and press style, the interesting and exact thought is as following: "For example, let's compare the attitude of the two features belonging to our literary language to the different style (artistic style and press style)." Both of these features are important for artistic style and press style. But if creating figurativeness and expressiveness by using artistic means is one of the duties of the artistic style and the heart of the artistic style, exactness is the main condition for the press style. Exactness, honesty is the first dignity of the press language. Of course, at times the artistic style is used in the press style too (Mehdiyeva, 2007).

\subsection{The Scientific Commentaries about the Press Organs as "Sherqi-Rus", "Molla Nasraddin" Published by the Nakhchivan Intellectuals}

In the system of the functional styles of the Azerbaijani literary language the press and the other information means have their specific place and specific features. After Hasan bey Zardabi founded the newspaper "Akinchi" at the end of XIX century our national press started to be active. Within a short period of time our national press played a great role in the development of Azerbaijani literary language.

The press organs which had been founded by the intellectuals of Nakhchivan-“Sherqi-Rus" ("Eastern-Russian") "Molla Nasraddin" ("Mullah Nasraddin") got rich experience in the field of publicism at the beginning of XX century and played a great role in the formation of the Azerbaijani literature and national press, and rose to the level of literary school. Our writers who worked in the field of publicism followed the events and processes of their time attentively and could be able to present the life realities happened in the people's life to the society. The language fact which once was considered the norm for the publicistic style but lost its urgency as a result of the development of the literary language displayed itself in the artistic publicism.

The representative of Nakhchivan literary environment Eyneli bey Sultanov explained the duty of the publicists as following: "The purpose of a publicist isn't to get material earnings. Because if it was so, in this case, the activity would be ungratefulness in itself. And to carry out that duty is twofold necessary. Publicist must study the spiritual life of his people enough and must be aware of the demand of the time (Shahverdiyev, 2006)."

A. Topchubashov remarked that the press expressed the thoughts of the people and played a great role in lightening the people's life and history. $\mathrm{He}$ wrote in his article titled "A Newspaper in Tatar language in Baku" ( ${ }^{\circ} 18$, January 23, 1905) published in "Kaspi" newspaper as follows: "All the Moslems who 
had healthy thinking welcomed gladly the news about mister Shahtakhtinski's getting permission to the publication of a newspaper in Tatar language." Among the first ones "Kaspi" also blessed "Sherqi-Rus" newspaper and congratulated the Moslem population on the occasion of renewing the social life and owning to the powerful means as the press organ in the native language (Topchubashov, 2018). A. Topchubashov put forward the opinion as "recently only Mohammad agha Shahtakhtinski had luck in the publication of mother-tongued newspaper, so, he welcomed the publication of the local newspaper."

Professor Afad Qurbanov generalized the language features belonging to the publicistic style, and the role of the vocabulary units in the characterizing of the publicistic style as following: 1) The social-political lexicon, the terms about science, culture, industry and other fields are used broadly. 2) In order to add a new color to the speech, the publicists use the new words. Archaism, and the words and phrases which are used in limited circle. 3) In order to criticize and unmask any target the sharp words and phrases are used (Qurbanov, 1992).

At the beginning of XX century the press organs as "Sherqi-Rus", "Molla Nasraddin", "Heyat", "Iqbal”, “Tereqqi", "Fuyuzat" alongside with broadening the opportunities of the publicistic style, also created good conditions for the democratizing, popularizing and enriching of our literary language. Academic Isa Habibbeyli draws attention to the fact that in the second half of XIX century the intellectuals from Nakhchivan cooperated with the press organs of Russia and the East. He writes as following about it: "To have cooperation with the press organs of that period influenced effectively to the development of the national enlightenment movement in that region." In the initiative of the local intellectuals from the different parts of the world some newspapers as "Tarcuman" (Bakhchysarai), "Heblulmetin" (Calcutta), "Sureyya", "Perverish" (Cairo), "Ekhter" (Tehran), "Novoye obozreniye" (Petersburg), "Kavkaz" (Tiflis) and other press organs were read and discussed by the enlighteners from Nakhchivan. Academic Isa Habibbeyli emphasizes that the writers from Nakhchivan had much experience in publicism and generalizes his thoughts as follows: "The researches prove that the newspaper 'Akinchi' was read in Nakhchivan. In the broadening of the press organs, the newspaper 'Sherqi-Rus' published by Mohammed agha Shahtakhtinski played an important role. The writers of Nakhchivan took an active part in the magazine 'Molla Nasraddin', which was published by the editor-in-chief Jalil Mammadquluzade (Habibbeyli, 2015).”

\subsection{The Rich Experience That the Intellectuals from Nakhchivan Got in the Field of the Press}

M. T. Sidqi, Q. Sherifzade, A. Qemkusar, J. Mammadquluzade, M. S. Ordubadi, M. Shahtakhtinski, H. Javid, E. Sultanov, E. Sebri, E. Mehbus and other writers published different articles on the pages of the newspapers and played important role in the enriching of press language that passed through specific historical stages, and its turning to the leading style of the Azerbaijan literary style. In the articles of our writers, they had emotionalism, strictness, deep analysis in the at- 
titude to the facts. In "Sherqi-Rus", "Molla Nasraddin" and other press organs there were published some interesting examples of the epic genre, as short and long story. Jalil Mammadqulusade's first work published in the press as the stories "Post box", "Game of raisin", "Barber", Aliqulu Qemkusar's first poem "Beginning in the village", M.S. Ordubadi's works "Edebiyyat", "Khabi-qeflet" which were published in the newspapers and magazines were met with the sympathy of the readers. The representatives of Nakhchivan literary environment used people's speaking language, means of artistic and expressional description, the examples from the folks, and their purpose in using such means was to rise the influencing strength of the articles and feuilletons. The readers read with interest such literary examples that were rich in figurative phrases.

\subsection{Mohammad Agha Shahtakhtli's Publicistic Activity}

Mohammad agha Shahtakhtinski published "Sherqi-Rus" (1903/1905) newspaper in Tiflis, and it was the only famous Azerbaijani newspaper. The eminent writers and poets as J. Mammadquluzade, M. A. Sabir, A. Nezmi, M. S. Ordubadi, Abdulla Tofiq Sur, H. Zardabi published their works on the pages of that newspaper. The newspaper gave great importance to the problems as enlightenment, culture, alphabet and language reform (Jalal, 2004). Altogether, the newspaper "Sherqi-Rus" gathered around it the group of intellectuals including the enlighteners Mirza Alakbar Sabir, Abbas Sehhet, Omar Faiq Nemanzade, Huseyn Javid, Mammad Said Ordubadi, Aliqulu Qemkusar, Eli Nezmi, and they played great role in awakening and educating of the nation. Our writers who wrote their works in publicistic style in order to reflect the people's language in their works, united the newspaper language on the level of phonetic, grammati$\mathrm{cal}$ and lexical norms. In the language of "Sherqi-Rus" there were a lot of Russian-European, Arabian-Persian originated terms and national terms. Starting from the beginning of XX century our intellectuals paid great attention to the problems of mother tongue and took an active part in clearing off the received words which spoiled our language. "In enriching the vocabulary of Azerbaijani language the words received from the Persian, Arabian and Russian languages have a great role. During the history of our language, some of our intellectuals had a strong inclination to the Persian and Arabian languages, and as a result, the advanced representatives of our science and culture criticized them on extreme level (Mehdiyeva, 2007).”

Our writers wrote their articles in the classic traditional style and people's speaking language which were specific for that period, and in this way, they achieved to secure the social-political interests of the publicistic style. The representatives of the literary environment who published specific articles on the pages of the newspapers and magazines displayed initiative to write in Arabian-Persian or Ottoman language. The difference of the lexicon of Azerbaijani literary language in XIX century on the functional styles proceeded with the same advantage came from the previous stage: in the literary-artistic language (artistic style) the increase of the satirical speech materials (rude words, abuses) 
were observed. In publicistic style from one side lexicon of national way of life, from another side, European-Russian originated lexicon was used, and in the scientific style different originated terminology, functional meaning difference strengthened (Khudiyev, 2012). Since the beginning of XX century alongside with forming strong inclination to the native language in the publicism of our writers the popularizing of the literary language, and enriching the language treasure of the people were felt.

Among the enlightenment ideas of M. Shahtakhtinski, alphabet, his struggle for the improved writing system takes a special place. It is right, such his idea was criticized by some intellectuals, especially by Ismayil bey Qasparli, Omer Faiq Nemanzade (Ashirli, 2009).

The author who appreciates the activity of M. Shahtakhtinski writes as follows: "M. Shahtakhtinski was the follower of the enlightenment movement that started from M. F. Akhundov, and he made efforts in creating national thinking, new school, new alphabet and press. Without a doubt, M. Shahtakhtinski began to all these from how the Transcaucasian Moslems were called and brought new mood to the national thinking (Ashirli, 2009)."

\section{The Role of "Molla Nasraddin" Magazine in the Development of Our Literary Language}

Like the important factor securing the improvement of our literary language in the magazine "Molla Nasraddin" the great place was given to the officialbusiness documents, the style problems, language and style exactness were always on the first plan. Our intellectuals who collaborated with that magazine drew the attention of the readers to the break of the grammatical norms of the literary language, damaging the aesthetic beauty of the style. At present time this problem is important for all the languages, so, in the article titled as "Qatish-bulash" (Mixed language) by A. Qemkusar was published in "Molla Nasraddin" journal (November 4, 1907, $\mathrm{N}^{\circ} 4$ ), he wrote about that problem in satirical language:

“Uncle Serker Mullah, I don't want to praise myself, I am a scientist completely in three languages: Turkish, Persian and Arabian languages. What do you think, in which language must I write for me to have virtue?" Then the author behaves as an ignorant person and remarks that it would be good to write the article in the three languages and in this way he critics the ignorant persons of his time in a satiric language: "Uncle Mullah, I don't want to offend anybody, if I don't write my article in the mixed language I won't feel relieved. I don't care whether the readers understand me or not. I am not the person who damages his virtue willingly (Qemkusar, 2006).”

In order to create satire, the writers of "Molla Nasraddin" magazine published the literary examples which reflected the speaking language of the people: sayings, proverbs, including phraseological units, social-political terms. Among the materials published on the pages of the magazine, there were examples of poems in which there were Arabian, Persian phrases. In the magazine, it is possible to 
see the examples of the expressions used by the people. The writers drew the attention of the readers by using sayings, proverbs and anecdotes.

Starting from the end of XIX century and the beginning of XX century on the pages of the newspapers and magazines the literary critics published the valuable research works about the struggle of Azerbaijan social thought for the pureness and simplicity of mother tongue, and exchanged their views. For the writers of "Molla Nasraddin" and the satirical representatives of other press organs it was specific the rude words, closeness to the people's speaking language, vulgar words in the vocabulary and syntax, the unmasking of the character with their own language, to give the meaning ironically (Afandiyeva, 1980).

In his book "The Aesthetics of the language" Aghamusa Akhundov drew the attention to the struggle of the magazines "Molla Nasraddin" and "Fuyuzat" in the struggle for the literary language at the beginning of XX century and wrote so: "From one side the realist-enlighteners, especially the representatives of revolutionary-democratic literature struggled for the simple language of the Azerbaijan, from other side the representatives of bourgeois literature put forward the language that looked like the Ottoman language from the practical view point and in some cases consisting of completely Ottoman language, and considered that language the only literary language of the Azerbaijani people (Akhundov, 1985)."

\subsection{The Language and Style Features of the Publicistic Style at the End of XIX Century and XX Century}

At the end of XIX century and at the beginning of XX century on the pages of “Tercuman" published by Ismayil Qasparli, the problems of joint Turkish literary language, and alphabet matters were discussed broadly. The representatives of Nakhchivan literary environment took an active part in those discussions. They played a great role in the discussion of the alphabet reform in the Near East that had been started by writer-dramatist Mirza Fatali Akhundov, at the same time his followers who struggled in this field, as Ismayil bey Qasparli, Uzeyir bey Hajibeyli, Jalil Mammadquluzade, Mohammad agha Shahtakhtinski and other eminent intellectuals wrote articles and feuilletons and tried to enlighten the people.

In modern life, the social subject has been turned to the spiritual need of the people. The opinions of linguist-scientist Turkan Afandiyeva who deals with the press-publicistic lexicon are estimable: "Undoubtedly, the expression of social-political lexicon displays itself in both of the styles. In publicistic style those units have the agitation-expressive function, the author has the right to appreciate all the facts and events. The author expresses both his subjective opinion and the opinion of some group or the opinion of any class in his language (Afandiyeva, 1980)."

At the end of XIX century and at the beginning of XX century a lot of words and phrases about the social-political life of that time were used in the publicistic style, and all of them had the universal feature. The use of social-political lexicon 
in the publicistic style displays itself distinctly. Such words related with the social-political life were used broadly in the language of the press: freedom, democracy, council, party, telegraph, post office, contribution, ignorance and etc.

At the beginning of XX century connected with the development of Azerbaijan realism there arose interest in the new literary styles, genres: plotted poetry, satirical poetry, artistic prose, dramaturgy, literary criticism, publicism.

It is possible to divide the European-Russian words that passed to the Azerbaijani literary language as perspective and without perspective words. Both the perspective and without perspective words were received because of the need to them, but the perspective words remain in the language and the words without perspective gradually leave the literary language (Khudiyev, 2012). The problems of culture, literature and language including literary translations were published in the press organs of that time.

It is necessary to reinvestigate the classic literature which is the carrier of our national-spiritual values, at the same time, to research its main sources, and including to appreciate the role of literature in our modern society and in the socially development. The newspapers and magazines which gathered around the most courageous and fighting publicists touched on the problems of the purity of our mother tongue and the urgent problems of daily life, and they turned those problems into words and delivered them to the people.

Altogether, the newspaper "Sherqi-Rus" gathered around it the group of intellectuals including the enlighteners Mirza Alakbar Sabir, Abbas Sahhat, Omar Faiq Nemanzade, Huseyn Javid, Mammad Said Ordubadi, Aluqulu Qemkusar, Ali Nezmi and they played a great role in awakening and educating of the nation. Our writers who wrote their works in publicistic style in order to reflect the people's language in their works, united the newspaper language on the level of phonetic, grammatical and lexical norms. In the language of "Sherqi-Rus" there were a lot of Russian-European, Arabian-Persian originated terms and national terms. "We open the columns of our newspaper with the explanation and description of any kind of thoughts not depending on whether they are philosophical, or religious, or social" (Newspaper "Sherqi-Rus",1903, N 1). M. Shahtakhtinski gave great importance to the disagreement, discussion of the groups of the society.

The representatives of Nakchivan literary environment presented their articles in the style of classical tradition and people's speaking language and in this way they could achieve to secure the social-political interests of the publicistic style. The writers who published their articles on the pages of the newspapers and magazines made efforts to avoid from the usage of the Arabian-Persian words, they tried to use simple words and phrases specific to the Azerbaijani language. With their new phrases, the writers enriched the vocabulary of the people's language and from another side, they propagated the literary language. Professor Abdulaziz Damirchizade remarked that the social-political style had two branches, and emphasized that one of those branches was the press style. "The base of the social-political style consists of the words and phrases which are understandable 
for everybody, here metaphorical and figurative meanings can't be as a system, but to use special examples of these ones is natural for this style (Demirchizade, 1962)."

The writer's publicissm is one of the most important, the most skilkful examples of the artistic publicism. In such kind of publicism the writer improves the text with the most convincing words and with the lexicon elements (Mammadli \& Mammadli, 2009).

At the beginning of XX century the authors who published their articles in the newspapers and magazines mostly used the rhetorical questions specific for the publicistic style knowingly because they knew that they wouldn't get the answers to the questions they had asked. The explanations of the problems they touched on were reflected in such kind of articles and feuilletons. In order to direct the attention of the readers to any kind of event the authors used interrogative and exclamatory sentences, and in this way, they could achieve different style colors. "Sincerity or impudence?", "When did it happen?", "Where is the real freedom?", "What is the newspaper?", "Maybe I am mistaken, let them say", "What did I see in Nakhchivan?" and etc.

Our writers as M. T. Sidqi, Q. Sherifzade, A. Qemkusar, J. Mammadquluzade, M. S. Ordubadi, M. Shahtakhtinski, H. Javid, E. Sultanov, E. Sebri, E. Mehbus published different articles in the press organs and played great role in the enriching Azerbaijani literary language and in turning the Azerbaijani language to the leading style of the literary language.

\subsection{Some Words about the Publicistic Activity of Aliqulu Qemkusar and Aziz Sherif}

The lexical units that the writers from Nakhchivan used in the publicism at the end of XIX century and at the beginning of XX century embraced the social-political life and that is why it is possible to imagine the scene of that time.

The writers from Nakhchivan benefited skillfully from the traditions of classic Azerbaijan, Eastern, Russian and world publicistic heritage including from the sayings, folklore and so played an exceptional role in the enriching of the history of national press. Aliqulu Qemkusar used the proverb "Though you tie the words to one another it is impossible to reach the past" in his feuilleton titled as "Ah, the past days" ("Molla Nasraddin", February 28, 1910, N9) and expressed his opinion shortly and perfectly. Aziz Sherif published feuilletons, articles, letters, and the examples of literary creation on the pages of the newspapers and magazines, and told his attitude to the social-political events and his critical thoughts allusively and used the language and style of the newspapers that had rich experience, and in this way could be able to address to the people. In his article titled as "Don't pass from the traitor's bridge let the stream take you away" he used from the proverbs and could strengthen his opinion about the end of the reaction powers. Aziz Sherif used some laconic phrases as "Anybody could be a Padishah if he could carry out what he said", and he could deliver his opinions in this way. 


\section{Conclusion}

The representatives of Nakchivan literary environment benefited from the variety of the genre and style and published articles in the newspapers and magazines they collaborated with and at present time their articles keep their importance from the historical viewpoint.

The eminent representatives of Nakhchivan literary environment-Mohammad Taghi Sidqi, Mohammad agha Shahtakhtli, Eyneli bey Sultanov, Elekber Qerib Nakhchivanli, Jalil Mammadquluzade, Mammad Said Ordubadi, Aliqulu Qemkusar, Huseyn Javid, Eli Sebri, Aziz Sherif who had a great role in the formation of publicism which is the many-branched genre, could reflect the word choice, vocabulary, the richness of artistic and publicistic heritage, language-style and phrase colorfulness in their articles and feuilletons.

\section{Conflicts of Interest}

The author declares no conflicts of interest regarding the publication of this paper.

\section{References}

Afandiyeva, T. (1980). Lexical Stylistic of Azerbaijani Language (250 p.). Elm.

Akhundov, A. (1985). The Aesthetics of the Language (224 p.). Yazichi.

Ashirli, A. (2009). Press History of Azerbaijan (1875-1920) (296 p.). Elm ve Tehsil.

Demirchizade, E. (1962). The Stylistics of Azerbaijani Literary Language (271 p.). Azertedrisneşr.

Fitzgerald, J. D. (2017). Nineteenth-Century Women Writers and the Sentimental Roots. Literary Journalism Studies, 9, 9-15.

Habibbeyli, I. (2015). From Nuhchikan to Nakhchivan (846 p.). Elm ve Tehsil.

Hajiyev, T. (2012). The History of Azerbaijani Literary Language (392 p.). Elm ve tehsil.

Jalal, M. (2004). Literary schools in Azerbaijan (1905-1917) (391 p.). Ziya-Nurlan.

Khudiyev, N. (2012). The History of Azerbaijani Literary Language (686 p.). Elm ve Tehsil.

Mammadli, J., \& Mammadli, A. (2009). The Eternal Influential Power of the Classics. History and Its Problems, 110-116.

Mehdiyeva, S. (2007) The History of Azerbaijani Literary Language (336 p.). Volume III, Sherq-Qerb.

Qemkusar, A. (2006). Selected Works (168 p.). Sherq-Qerb.

Qurbanov, A. (1992). Language and style (46 p.). APU Press.

Shahverdiyev, A. (2006). The History of Azerbaijan Press (248 p.). Tehsil.

Topchubashov, A. B. (2018). Selected Works from "Kaspi”(128 p.). Zardabi Ltd., MMC. 